DOI: $10.20472 / S S .2015 .4 .3 .005$

\title{
AIDING INNOVATION AND ENTREPRENEURSHIP THROUGH MIGRATION POLICY: A VIEW FROM AUSTRALIA
}

\section{KHANH HOANG}

\begin{abstract}
:
In recent years, there has been significant interest in the role of migration policy in aiding innovation, entrepreneurship and economic growth. The weight of academic literature points to a positive relationship between migration and innovation. Several countries, including Australia, Canada, the US and Singapore have sought to leverage this relationship by establishing various visas aimed at attracting migrant entrepreneurs and monetary investment from high net worth individuals to support their innovation systems.
\end{abstract}

This paper analyses the effectiveness of Australia's migration policies in strengthening its innovation system and asks what, if anything, could be done differently. Two key areas of the innovation system that could be addressed through migration policy are identified: increasing the pool of venture capital in Australia and attracting more migrants with entrepreneurial talent. Established in 2012, Australia's Business Innovation and Investment Programme (BIIP) contains a range of visas aimed at attracting entrepreneurs and investment from high net worth individuals but has largely failed to address the needs of the innovation system. Drawing upon experiences of other jurisdictions and evidence from internal stakeholders, this paper suggests a range of reforms to the BIIP that would better align migration and innovation policy in Australia. Whilst approaches to the innovation and migration nexus will differ from economy to economy, Australia's experiences may provide valuable lessons for other countries seeking to establish similar visa programs.

\section{Keywords:}

migration, innovation, entrepreneurship, government policy, economics

JEL Classification: F22, K37, 038

\section{Authors:}

KHANH HOANG, ANU College of Law, Australian National University , Australia , Email: khanh.hoang@anu.edu.au

\section{Citation:}

KHANH HOANG (2015). Aiding innovation and entrepreneurship through migration policy: A view from Australia. International Journal of Social Sciences, Vol. IV(3), pp. 59-81., 10.20472/SS.2015.4.3.005 


\section{Introduction}

It has long been recognized that innovation and entrepreneurship play an important role in contributing to economic growth and development (Schumpeter 1934). In a globalized world marked by fluid movements of both human and economic capital, economies are competing with each other to attract and retain entrepreneurial talent, as well as securing economic investment from high net-worth individuals to support their innovation systems. Policymakers are grappling with how to best align migration and innovation policy. This paper examines the effectiveness of Australia's migration policies in aiding and innovation and entrepreneurship, and discusses what, if anything could be done differently.

The paper has four parts. Part I examines the links between migration and innovation, finding that existing literature points to a positive relationship between the two. Part II examines Australia's innovation system and identifies two key areas where migration policy could make a positive contribution: attracting migrants with business acumen and entrepreneurial talent; and strengthening the venture capital industry by facilitating migration of, and investment from, high net-worth individuals.

Part III examines Australia's Business Innovation and Investment Programme (BIIP) and describes the range of visas available to entrepreneurs and high net-worth individuals. The BIIP was established in 2012 with the core aim of contributing to Australia's innovation system but has largely failed to deliver on its promised benefits. Part IV analyses some recent reforms to the BIIP. In addition, it draws upon experiences from other jurisdictions, as well as anecdotal evidence from domestic stakeholders to propose a range of other reforms to the BIIP that would benefit Australia's innovation system.

It is hoped that Australia's experience with the BIIP and the reform proposals will provide valuable lessons for other economies looking to set up similar visa programs.

\section{The link between migration and innovation}

Despite a growing body of literature, the migration and innovation nexus remains an under-researched area of policy. While migration debates in the media are largely negative - focusing, for example, on perceived threats to local jobs and security concerns - policymakers recognize that migration can stimulate innovation and economic growth (Jensen 2014). While it is difficult to conclusively determine how migration contributes positively to innovation and productivity, the literature suggests that there is a positive relationship between the two. In particular, studies have suggested that migration can contribute to the innovation system in three main ways: diversification of skills and knowledge; positive spillovers; and the creation of a 'creative class'. 
First, migrants may benefit the innovation system by bringing a diversity of knowledge and ideas, and thereby complementing the skills of the local labor force (Neibuhr 2006). For example, Neibuhr found that regions in Germany with a more culturally diverse workforce (consisting of different nationalities) had higher levels of innovation activity. Bosetti, Cattaneo and Verdolini (2012) also found, using patent application rates and citations in scientific publications across 20 European countries, that greater diversity increases innovation performance through cross-cultural interaction and approaches to problem solving.

This may suggest that migrants themselves have a propensity to innovate or invest in new skills (Duleep, Jaeger \& Regets 2012). Stephan and Levin (2001) examined the productivity of immigrants vis-à-vis natives in the field of science in the United States. After accounting for a range of different indicators of excellence, they found that immigrants made more exceptional contributions to US science than their domestic counterparts. However, this may simply be a reflection of migrants' preference to study in areas such as science and engineering (Hunt \& Gauthier-Loiselle 2009).

Secondly, increased migration may result in positive spillovers for the innovation system. Hunt and Gauthier-Loiselle (2009) suggested that a one percentage point increase in US migrants with college degrees could benefit the national patenting rate by as high as a $9-18 \%$ per capita, due to positive spillovers to fellow US-born researchers. A follow-up study by Islam, Islam and Chau (2014) using the National Survey of College Graduates and US Census datasets found that the innovation propensity of immigrants appeared to increase wages for both natives and immigrants. Another study found that increases in the enrolment of foreign graduate students in American universities led to statistically significant increases in future patenting. This effect was said to be even larger than the effect on patenting flowing from skilled migration (Chellaraj, Maskus \& Mattoo 2005).

Thirdly, successful migration policies may in the long run contribute to the innovation system through the creation of the 'creative class' or innovation clusters. Florida (2003) argues that the presence of large numbers of workers in creative fields in a given country would attract like-minded workers to move to and live in the same place, thereby adding to human capital. Similarly, Zucker and Darby (2007) argue that many top-level scientists choose to migrate to economies where there are clusters of likeminded innovators.

While the focus of research to date has been on the effects of human capital migration on the innovation system, there is also increasing policy focus on attracting economic investment from high net worth individuals. In the past decade, Australia, the UK, Singapore, Canada, and the US have all offered investor visas that seek to trade monetary investment in return for permanent residency or citizenship. However, no 
comparative research has been done into the effectiveness of these visas programs in aiding innovation and entrepreneurship.

The weight of academic literature paints a positive picture of the migration-innovation relationship. However, the policy challenge is not, in and of itself, about attracting more money or immigrants. Policymakers need to ensure that migration outcomes result in a net positive contribution to innovation systems. That is, they need to ask: how can immigration policies be designed to attract and retain the best talent and foster innovation and entrepreneurship? And more importantly, what are the optimal parameters within a migration system that will maximize net positive contributions to the innovation system?

\section{Australia's innovation system and the role of migration policy}

This section considers the migration and innovation nexus in relation to Australia. A starting point is to determine what, if any, gaps or deficiencies exist in Australia's innovation system before considering how migration policy might best be designed to address such gaps. Two key deficiencies are identified: attracting more entrepreneurial and business talent and increasing the pool venture capital available for entrepreneurs.

Historically, Australia's innovation policy has been based on a free-market approach, with little by way of government coordination or intervention (Hughes et al 2011). However, recent Australian governments have turned their minds to the importance of a cohesive and integrated innovation framework that covers a spectrum of policy areas, including: taxation, intellectual property, research and development, and migration. In relation to migration, the Australian Government has declared Australia 'open for business' and its Industry Innovation and Competitiveness Agenda requires Australia to pursue 'a more skilled labour force' and 'industry policy that fosters innovation and entrepreneurship' (Australian Government 2014, p.3).

Both innovation and entrepreneurship are difficult metrics to precisely define and measure. The OECD defines innovation as the implementation of a new or significantly improved product (good or services) or process, a new marketing method, or a new organisational method in business practices, workplace organisation or external relations' (OECD 2005, p. 46). Entrepreneurship is intrinsically linked to innovation, since they are viewed as innovators who implement entrepreneurial change within markets (Schumpeter 1934). Entrepreneurs can also be broadly described as risk-takers and business owners (Knight 1921).

How is the innovation system faring in Australia? One well-accepted proxy to measure innovation is multi-factor productivity (MFP), which reflects improvement in efficiency that is 'fostered through investment in innovation, improved management, and skills development' (Department of Innovation, Industry, Science and Research 2009, p.3). 
Figure 1: PRODUCTIVITY MEASURES, Quality adjusted hours worked basis

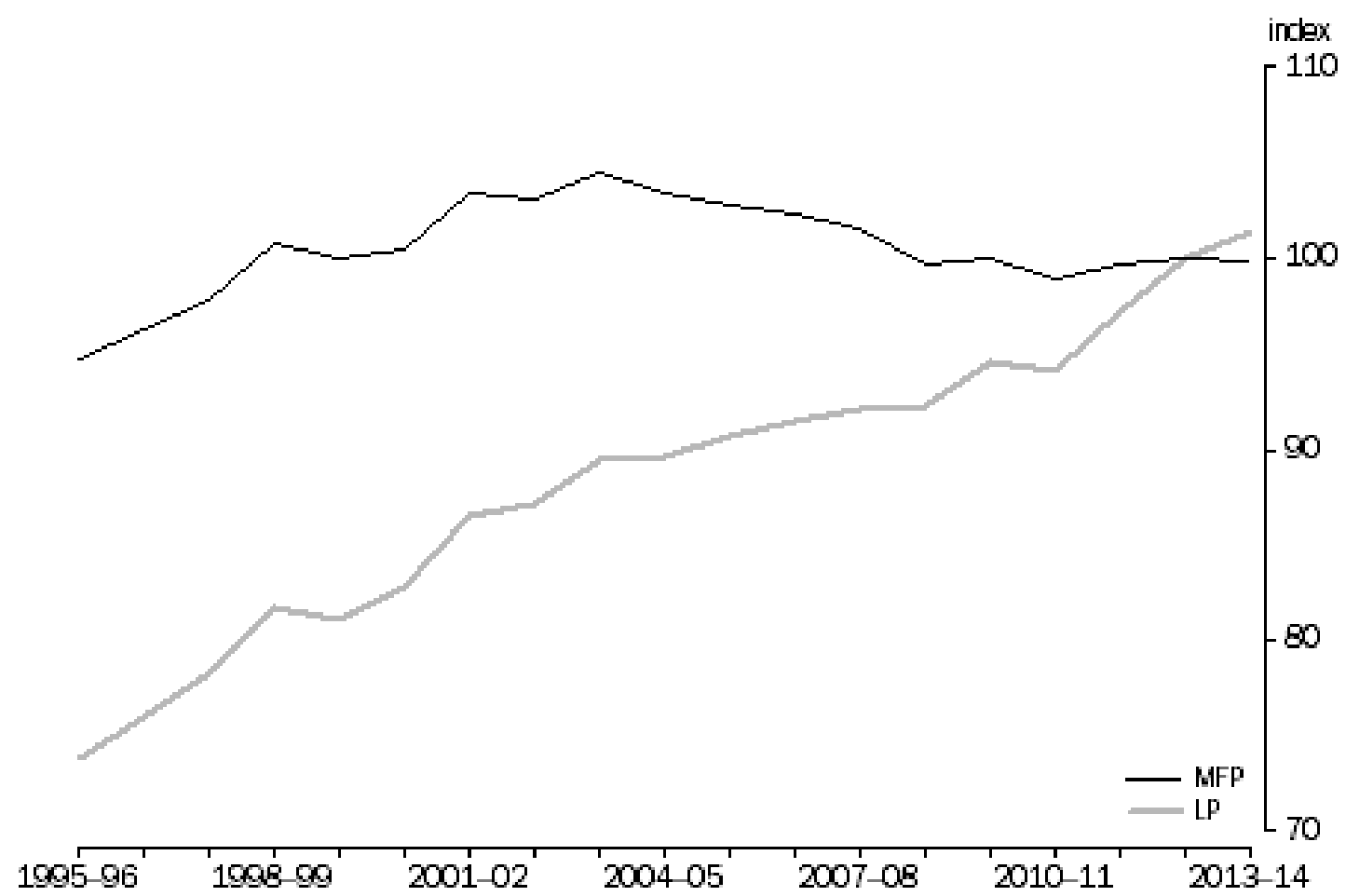

Source: Australian Bureau of Statistics 5260.0.55.002 - Estimates of Industry Multifactor Productivity, 2013-14

Data from the Australian Bureau of Statistics (2014) shows that MFP has been stagnant in Australia since 2003. In a 2008 report, Venturous Australia, it was suggested that Australia's innovation system 'seems to have slowed, or even stalled in the new millennium' (Cutler 2008, p.13). The report argued that Australia's ability to tap into global talent pools is critical to the innovation system, and recommended that 'innovation policy should be aligned with migration policies' by ensuring that human capital 'carry equal or more weight than economic capital in individual migration assessments' (Cutler 2008, p. 60). In the same year, the then Department of Immigration and Citizenship also recognized that 'migrants contribute disproportionately to innovation and entrepreneurship and the opening up to new trade markets' (Department of Immigration and Citizenship 2009, p.18).

\section{Access to funds, skilled labor and entrepreneurs}

Despite the recommendations in Venturous Australia, the innovation system has not progressed in the ensuing years. Data from the Australian Bureau of Statistics (2014b) show that lack of funds, access to skilled persons and knowledge to enable product 
development and implementation remain significant barriers to innovation for 'innovation active' businesses in Australia.'

Table 1

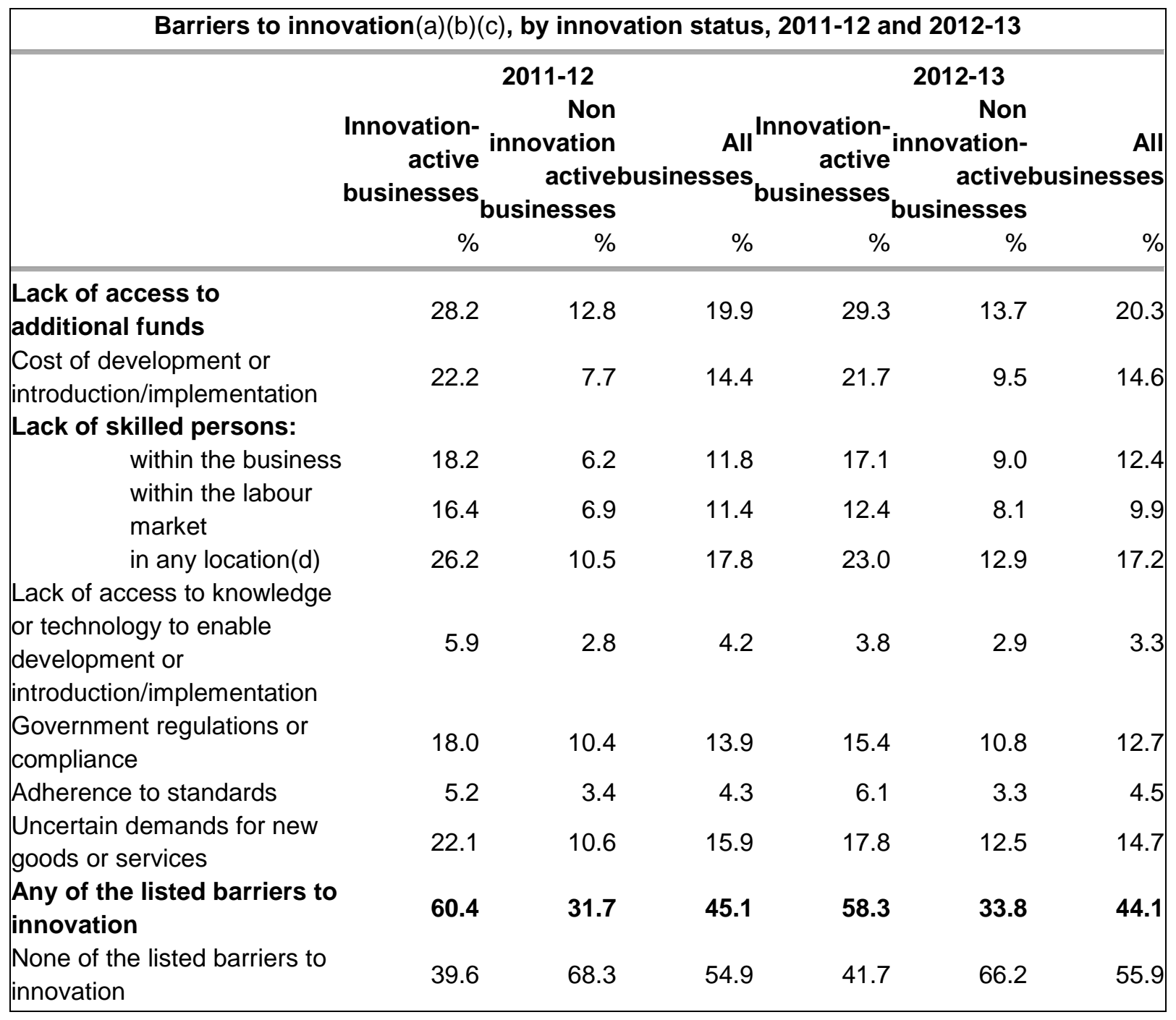

Source: Australian Bureau of Statistics: 8158.0 - Innovation in Australian Business, Barriers to Innovation 2012-13

The ability to access skilled persons and entrepreneurs will remain an ongoing challenge for Australia's economy. The Department of Industry and Science (2014, p. 158) reported Australia will face skills shortages of up to '2.8 million in supply of at least diploma qualifications by 2025 ' and that 'migration will therefore continue to be a

\footnotetext{
${ }^{1}$ For the purposes of the ABS data, 'innovation-active businesses' are those that undertook any innovative activity during the reference period. This includes businesses that introduced or abandoned any of the four types of innovation (new or significantly improved goods or services, operational processes, organisational/managerial processes, and marketing methods) and those that had any of the types of innovation still in development at the end of the period.
} 
key strategy for addressing these challenges' tied to enhancing the capacity to innovate and compete.

\section{Access to venture capital in Australia}

A neglected area of Australia's innovation system is its venture capital industry. Venture capital provides an important source of funding for entrepreneurs of start-up businesses, especially in the information, communications and technology sector and research sector in the development phase. In overseas jurisdictions, companies such as Google, Apple, Starbucks and CISCO were all recipients of venture capital funding during their growth cycles. According to the Australian Private Equity and Venture Capital Association (AVCAL) - the industry body for venture capital in Australia venture capital availability has substantially dried up in Australia. Its data suggests that venture capital funds raised in Australia in the financial years between 2009-2013 amounted to only $65 \%$ of the funds raised in the previous five years (AVCAL 2014). Australia ranks behind many other OECD countries in venture capital investment as a percentage of GDP (OECD 2013, p. 89). ${ }^{2}$

Figure 2

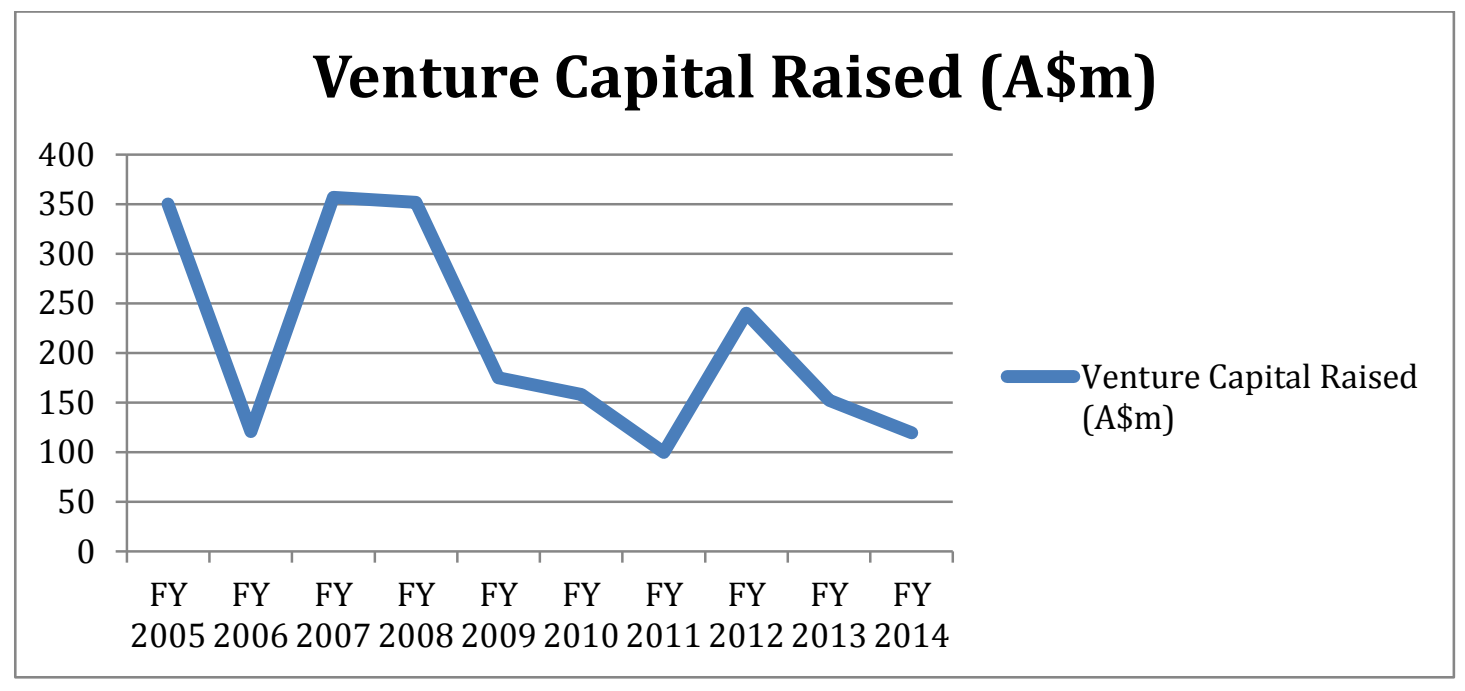

Source: AVCAL, 2014 Yearbook: Australian Private Equity and Venture Capital Activity Report.

The reduction in access to venture capital has severely hampered the ability of Australian start-ups and small companies to engage in innovation. In 2012, the Australian Treasury found that while there is no shortage of globally competitive opportunities being generated from Australian ideas and research ... many opportunities are not being progressed' due to lack of capital (The Treasury and the Department of Industry, Innovation, Science, Research and Tertiary Education 2009, p.14). AVCAL is of the view that the full economic effects of venture capital 'remain

\footnotetext{
2 In terms of venture capital investment as a percentage as a percentage of GDP (US), Australia ranks $23^{\text {rd }}$ behind much smaller economies including Israel, Hungary, Netherlands and Norway.
} 
largely unfilled in Australia' and that 'private sector investment in this sector is unlikely to see any significant uplift unless there is a strong policy signal of Government support in this regard' (AVCAL 2014, Submission to Review of the Innovation System, p.3).

\section{Australia's Business Innovation and Investment Program (BIIP)}

\section{Overview}

The BIIP was introduced in 2012 to reform Australia's business migration program in order to 'increase entrepreneurial talent and diversify business expertise in Australia' (DIBP 2015a). In particular, the objectives of the program are to, inter alia: generate employment; increase production and export of goods and services; introduce new or improved technology; increase competition and commercial activity and develop links with international markets. It was expected that the BIIP would improve the business migration program to contribute to the national innovation system by selecting and fostering innovation to meet Australia's economic needs (Department of Immigration and Citizenship 2012).

The BIIP superseded the previous Business Skills Program by reducing the number of business visa classes from 13 to three. These are:

- Business Talent (Permanent) Subclass 132 visa;

- Business Innovation and Investment (Provisional) Subclass 188 visa; and

- Business Innovation and Investment (Permanent) Subclass 888 visa.

As discussed below, under each of these visa classes there are a number of different streams, each with different eligibility requirements. Broadly, the BIIP can be divided into visa streams that seek to attract human capital (entrepreneurial or business talent) and economic capital (monetary investment from high net-worth individuals). All criteria for the grant visas discussed below can be found in the Migration Regulations $1994 .^{3}$

There are 'common criteria' that apply across all the visa subclasses. These require that an applicant lodge an 'expression of interest' (EOI) to apply for the visa on a SkillsSelect database. The EOI is an online tool that allows an applicant to self-assess whether they meet the eligibility criteria for the grant of the visa. As part of an EOI, applicants must indicate which visa they are applying for as well their preferred State or Territory.

In order to make an application for a visa, an applicant must first be nominated by a state or territory government and be invited to apply for the visa. State and territory

\footnotetext{
${ }^{3}$ Visa criteria can be found in Schedule 2 to the Migration Regulations 1994 (Cth). Each subclass of visa has a three-digit code and the criteria for the grant of the visa can be found under the relevant clause. For example, the criteria for the grant of the subclass 188 visa can be found under cls 188.111-188.612.
} 
governments can select applicants who have made an EOI through the SkillsSelect database, and nominate applicants who match their nomination criteria. The idea is to allow states and territories to select applicants who will make a significant contribution to their economy and innovation system.

A few other features of the BIIP are worth noting. First, with the exception of the Business Talent (Permanent) Subclass 132 visa, all other visas under the BIIP have a two-stage process to permanent residency. This requires an applicant to hold a provisional (Subclass 188) visa for at least four years before being eligible to apply for the Permanent (Subclass 888) visa.

Second, visas are subject to stringent financial criteria. These relate to either the net assets owned by the applicant and/or the amount of money an applicant must invest or be willing to transfer to Australia as the holder of the visa.

Lastly, the provisional visa (Subclass 188) visa also requires applicants to score at least 65 points on the 'innovation points test'. The test uses a range of criteria to measure a person's suitability for the program, including: age, English language ability, personal and business assets, business history and innovation. The innovation points test can be found in Appendix $\mathbf{A}$.

\section{The Business Talent (Permanent) Subclass 132 visa}

This is a permanent visa with two streams: the Significant Business History Stream and the Venture Capital Entrepreneur Stream.

The Significant Business History Scheme is intended to attract persons who have a bona fide interest in doing business in Australia, a proven business history, and the ability to run a business in Australia. Applicants must have a genuine and realistic commitment to establish a business in Australia or participate in an existing business in Australia and must have AUD $\$ 1.5$ million in net assets that can be transferred to Australia within two years of the visa being granted. In addition, the applicant must demonstrate in two of the four years immediately before the application that they have:

- total net assets of at least AUD $\$ 400,000$ as ownership interest in one or more qualifying businesses; or

- have at least AUD \$3 million turnover in one or more businesses; or

- ownership interest of at least: $51 \%$ in a business with less than AUD $\$ 400,000$ turnover a year; 30\% in a business with more than AUD \$400,000 turnover a year; or $10 \%$ in publicly listed company (ownership interest test).

The Venture Capital Entrepreneur stream is intended to bring 'foreign entrepreneurial expertise to Australia's innovation system' (DIBP 2014, p.11). Applicants for this stream must have entered into a legally binding agreement with an Australian 
company who is a member of AVCAL to receive funding for venture capital for the early start-up phase, commercialization, development or expansion of a high value business idea in Australia. The amount of venture capital provided under the agreement must be at least AUD $\$ 1,000,000$. As of 12 May 2014, only one applicant had applied for this visa under the BIIP (DIBP 2014, p. 11).

\section{The Business Innovation and Investment (Subclass 188 (Provisional)) and (Subclass 888 (Permanent)) visas}

The Business Innovation and Investment visa has three streams: the Business Innovation Stream, the Investor Stream and the Significant Investor Stream. This visa is a provisional visa that allows an applicant to stay in Australia for up four years, after which they can apply for a permanent visa (Subclass 888).

There are common criteria across these streams. These require that the applicant: be less than 55 years old; have a proven successful business history or investment record; have no involvement with unacceptable business or investment activities and have a bona fide realistic commitment to reside, own or manage the investment in the state or territory nominated.

Applicants for the business innovation stream must score at least 65 points in the innovation points test. In addition, they must have in the two of the four fiscal years before the time of invitation to apply for the visa, held ownership interest in a business that an annual turnover of AUD $\$ 500,000$ in each of those years. The applicant and/or the applicant's spouse must have at least AUD $\$ 800,000$ in net assets. Similar to the Business Talent (Subclass 132) visa, the applicant must pass the ownership interest test.

The holder of a business innovation stream visa may be eligible for a permanent subclass 888 visa if they can demonstrate that in the year immediately before the application their nominated business had an annual turnover of at least AUD $\$ 300,000$. In addition, the applicant must demonstrate that they achieved two of the following three requirements:

- Earned a net value of business assets of AUD $\$ 200,000$ in the nominated business; or

- Have net value of personal and business assets of at least AUD $\$ 600,000$ in Australia; or

- Employed at least two full-time employees in the nominated business who are not family members and who are Australian citizens or permanent residents.

Under the investor stream, an applicant must also score 65 points on the innovation points test. In addition, the applicant must have had three years' direct involvement in an investment or business and must demonstrate a high level of management skill in relation to the investment or business activity. Applicants must have AUD \$2.25 million 
in net assets and must make a 'designated investment' of AUD $\$ 1.5$ million to be held for four years in the State or Territory where they are nominated. A 'designated investment' is defined by legislative instrument to include state or territory government bonds (Migration Regulations 1994 (Cth); Legislative Instrument IMMI 12/106). The applicant must also have an intention to live in the state or territory of the investment for at least two years.

Under the significant investor visa stream (SIV), the applicant must invest AUD \$5 million in a 'complying investment'. A 'complying investment' is defined by the Migration Regulations 1994 (Cth) (reg 5.19B) and Legislative Instrument IMMI 13/092 to include one or more of the following:

- an investment in a government bond of the Commonwealth, a State or Territory; or

- a direct investment (ownership in a company) in an Australian proprietary company that is not listed on the Australian stock exchange; or

- an investment in a managed fund that is specified in a legislative instrument. This includes funds that invest in infrastructure projects, real property, bonds and annuities.

An applicant must evidence an intention to hold the complying investment for four years and must be resident in Australia 40 days for every year or the secondary applicant (spouse of the applicant) must be reside in Australia for 180 days a year. If the 'complying investment' is held for four years, applicants may be eligible for the Subclass 888 permanent visa. Unlike the other streams of this visa, applicants are not required to meet the innovation points test or age requirement.

On 17 October 2014, the Australian Government announced that it would introduce the Premium Significant Investor Visa (PIV) (Robb 2014). This visa essentially provides a quicker ticket to permanent residency by allowing holders to apply for permanent residency after holding a provisional visa for 12 months. The visa will require a minimum investment of $\$ 15$ million into complying investments. Further, the primary visa holder is not required to reside in Australia. The visa will come into effect on 1 July 2015.

\section{The need for reform}

On its face, the BIIP was an attempt to align migration and innovation policy in the manner recommended by Venturous Australia and other reports. However, since the BIIP was introduced there has been a significant drop in the number of applications and a general concern amongst stakeholders that the program is not meeting its intended objectives. This section analyses recent reform made to the Significant 
Investor Visa stream, and provides further suggestions for reform of other areas of the BIIP.

On 14 March 2014, the Australian Government asked the Australian Senate Joint Standing Committee on Migration (JSCM) to inquire into and report on the state of the BIIP. The review specifically excluded the significant investor visa program, which was subject to a separate review by Australia's Trade Commission, Austrade. The JSCM was asked to: assess whether the BIIP was meeting its objectives; consider the conditions involved in declining application rates; evaluate whether the current eligibility requirements are effective; and weigh up the size of the BIIP against emphasis on other skilled visas in generating economic growth (JCSM 2015).

The JSCM delivered its report on 24 March 2015. Despite receiving submissions from a wide range of stakeholders, the Committee did not make any concrete recommendations for reform. Rather, it recommended that the BIIP be subject to further review by the Department of Immigration and Border Protection. However, the Committee did question, on the available evidence, 'whether the BIIP is effective in attracting high quality business migrants to fulfill Australia's innovation requirements' (JSCM 2015, p. 30).

\section{Increasing the pool of venture capital through reform of Significant Investor Visas}

Since its inception, there has been significant demand for the SIV visa. As of 31 March 2015, 'complying investments' made under the program have totaled AUD $\$ 3.755$ billion, with a further AUD $\$ 2.770$ billion of proposed investment in the pipeline (DIBP 2015b). However, the structure of the SIV program has meant that investment has not flowed to the venture capital industry, where it is most needed. Rather, the current structures have created a situation where SIV applicants are 'not basing business decisions on investment return, or opportunity market factors but rather on safety and convenience (Northern Territory Government 2015). The South Australian Government noted that 'essentially all SIV applicants have chosen to invest in state and territory bonds' (South Australian Government 2015).

One proposal for reform is to widen the list of eligible investments to allow 'for investment into professionally-managed Australian venture capital funds'. (AVCAL 2015). However, this proposal would still rely on visa applicants exercising their discretion to invest in venture capital funds that inherently pose more risk. Given the propensity of applicants to undertake safe investments, it is argued that this proposal would not, of itself, result in a windfall to the venture capital industry. 


\section{Mandatory investment into venture capital funds}

On 14 May 2015, the Australian Government announced that it would reform the 'complying investment' criterion of the SIV, with effect from 1 July 2015, to require mandatory investment of:

- at least AUD $\$ 500,000$ in eligible venture capital or growth private equity funds investing in small start-up companies;

- at least AUS $\$ 1.5$ million in an eligible managed fund that invests in emerging companies listed on the Australian Securities Exchange (ASX); and

- a 'balanced investment' of up to AUD \$3 million in managed funds that invest in a combination of eligible assets that include bonds, annuities, ASX listed companies and real property (Austrade 2015) .

The government also expects to increase the threshold amount of venture capital investment to AUD \$1 million within two years as the market responds. These reforms flowed from a review into the 'complying investment' criterion by Austrade, which recommended that the investment criterion be amended to require AUD \$1 million investment in venture capital (Austrade 2015b).

These changes to the complying investment criterion should be applauded as a necessary step in aligning migration and innovation policy. AVCAL estimates that of the AUD \$3 billion of proposed 'complying investments', channeling $20 \%$ of that pool into Australian venture capital or private equity sectors could produce a $\$ 600$ million increase in business investment in Australia, or up to $\$ 1.8$ billion if $60 \%$ of the current pool is invested (AVCAL 2014b). Mandatory investment should increase the pool of venture capital available to local entrepreneurs, a well as opening up more opportunities for migrant entrepreneurs to seek funding under the Venture Capital Entrepreneur stream. As noted above, not one Venture Capital Entrepreneur visa has been granted since the BIIP has been in operation and this is largely due to the limited availability of venture capital in Australia, and the requirement that the applicant have sourced \$1 million in venture capital funding (AVCAL 2014c).

Mandatory investment into emerging companies should also help more 'innovationactive' businesses to receive adequate funding to carry out their activities and have adequate resources to attract skilled labor.

Given the significant demand for the SIV over its lifetime, a mandatory investment of $\$ 500,000$ should not significantly affect demand. It is worth noting that while venture capital investments carry risk, there is also scope for higher returns.

Further, under the reforms the SIV still compares favorably with the approaches taken in other jurisdictions. For example, in Singapore, the Global Investor Program requires applicants to invest at least SGD 2.5 million into a venture or growth capital fund that invests in Singapore-based companies (Singapore Economic Development Board 
2015). A similar pilot program was set up by Canada in early 2015. Under the Immigrant Investor Venture Capital (IIVC) pilot program, an applicant is required to invest CAD $\$ 2$ million into the IIVC fund for 15 years. The IIVC fund is managed by the Business Development Bank of Canada and will invest funds in Canadian startups with high growth potential. Investments are at-risk investments, meaning that an applicant may lose some or all of their money (Government of Canada, 2015).

\section{Co-investment from government}

While reform of the 'complying investment' would make the SIV more internationally competitive, it is questionable whether the $\$ 500,000$ threshold will provide sufficient stimulus to the venture capital industry in the long-term. The Australian Government ought to further leverage the SIV (and potentially PIV program) to ensure the longterm security of the venture capital industry in Australia through co-investment schemes.

Evidence from other jurisdictions suggest that co-investment from government forms an important part of a healthy venture capital industry. For example, the UK Government supports innovation through the UK Innovation Investment Fund (UKIIF). This UKIIF invests in two underlying funds, which undertake venture capital investments in businesses with high growth potential in digital technologies, clean energy and advanced manufacturing. In September 2012, an early evaluation of the fund concluded that it had encouraged private investment leverage of $£ 170$ million, in addition to the $£ 150$ million from the government. The evaluation found that the 'overall impact on recipient businesses' development appear greater than its investment levels' (Department for Business Innovation and Skills 2012, p.63).

In Singapore, the government runs the Early Stage Venture Fund (ESVF). Under the ESVF, the government - through the National Research Foundation - invests SGD $\$ 10$ million on a dollar-for-dollar matching basis to seed venture capital funds that invest in Singapore-based early stage high-tech companies. Private investors are provided with the added incentive of being able to buy out the government's share of the fund within five years by returning the government's capital with interest. The first batch of venture capital funds were announced in 2009, with a further six funds announced in April 2014. A number of success stories have developed from the program (National Research Foundation 2015).

The Singapore Government also has a SPRING Startup Enterprise Development Scheme (SPRING SEEDS), whereby a subsidiary of a government agency, Spring Singapore, co-invests with independent third parties in commercially viable Singapore start-ups dollar for dollar up to the value of $\$ 2$ million (Spring Singapore, 2015).

The Australian Government should consider setting up similar venture capital coinvestment schemes, whereby it could match venture capital investments generated 
through the SIV or PIV. This would strengthen the future of the venture capital industry, and may have the flow-on effects of encouraging uptake in private investment, as has occurred the UK.

\section{Relaxing other stringent criteria under the BIIP Program}

While the SIV has recorded significant demand, other visas under the BIIP are underperforming. Reforms are needed in to make both the Subclass 132 and 188 visas more attractive to prospective applicants. A common concern among many stakeholders to the JSCM Inquiry was that the entry requirements for these visas are excessively high compared to the previous business visa scheme (Van Zyl 2014; Migration Institute of Australia 2014). Stakeholders who submitted to the JSCM Inquiry called for a range of reforms to the eligibility criteria for BIIP visas, including:

- removal the two-stage visa process, as this increases the risk for potential business owners or investors of migrating to Australia;

- removal or reduction of the 'innovation points' test;

- a reduction in the total 'net assets' and business turnover requirements for a Significant Business History visa in line with other jurisdictions; and

- a reduction of the venture capital investment threshold for a Venture Capital Entrepreneur visa from $\$ 1$ million to $\$ 100,000$.

It is argued that each of these reforms proposals should be implemented.

\section{Removal or reform of two-stage visa process}

A chief concern among stakeholders is that the BIIP visas - apart from the Business Talent visa - require a person to hold a provisional visa for a period of four years before transitioning to a permanent visa. This was said to dissuade many potential migrants, who are unwilling to take the risk of moving their businesses or investments to Australia without a clear pathway to permanent residence or citizenship (Levingston 2014). With such high risks, applicants have sought to maximize their chances of permanent residency while minimizing the risk of financial loss (Migration Institute of Australia 2014). That is, despite possessing entrepreneurial talent or business acumen, visa holders may choose to the safe option of buying existing businesses rather than taking a risk on new enterprises, or choose safe 'complying investments' instead of higher risk venture capital investments. For this reason, it is argued that 'investment and other outcomes such as increased trade, improved use of technology and greater levels of innovation have not materialized throughout the life of the BIIP' (South Australian Government 2014, p. 7). 
Under the current structure, the applicant bears the majority of risk in relocating their business or investments to Australia, with little certainty of permanent residency. Removal of the two-stage visa process would provide a policy signal that the Australian Government is also willing to bear some of the risk of taking on migrant investors and entrepreneurs. If removal of the two- staged process is not pursued, at the very least the BIIP should be reformed to 'provide very simple and predictable rules for the transition from temporary to permanent residence' (Immigration Solution Lawyers 2014, p.9).

\section{Removal or reform of the 'innovation points' test}

The imposition of the 'innovation points test' is also said to be a significant barrier to the BIIP's ability to attract migrant entrepreneurs. The Act Government (2104) argued that the points test 'tends to assess the individual rather than the demonstrated business acumen that is required to establish and operate a successful business in a new country' (ACT Government 2014). For example, a person with a highly successful track record of investment or business history could be rejected on the basis of the English language requirement, a criterion that says little about the likelihood of future success. Further, this criterion has a significant impact on important source markets such as China where the proportion of English language speakers is low (Government of South Australia 2014, p.16).

In this sense, the points test is a 'blunt instrument' and focus is better diverted towards assessment of the applicant's demonstrated business or investment acumen (NT Government 2014; Van Zyl 2014). It is suggested that reform could include removal of English or age requirements from the innovation points test and thus lowering the points test threshold, or removal of the points test altogether. However, an argument in favor of keeping, but reducing the points test threshold is that the points test provides a objective criteria by which to distinguish prospective applicants.

\section{Reduction in threshold monetary asset or investment amounts}

Another potential reform lies in reducing the threshold net assets or investment criterion for BIIP visas. In a survey conducted by the Migration Institute of Australia, $90 \%$ of its members reported a fall in business skills visas applications since the BIIP was introduced, and $80 \%$ advised that this was due to the higher monetary thresholds (MIA 2014). A number of stakeholders called for a reduction in the threshold monetary amounts to attract greater numbers fearing that Australia is losing entrepreneurial talent to other countries (MIA 2014; NSW Trade and Investment 2014; Rockwell Oliver 2014). The Australian British Chamber of Business and Commerce (as cited in Commonwealth of Australia 2014, p. 2) observed that:

We are looking for entrepreneurs and investors, but it is interesting that, in those countries which are trying to be restrictive, you seem to have a much lower 
threshold for your investors and entrepreneurs. The entrepreneur visa in the UK is $£ 200,000$ and, in some cases, if certain government programs are sponsoring the project you are on, it is as little as $£ 50,000$... if I am going to set up a new business, I have 65 million-plus people in the UK to market to versus 22 million here. If you are going to make it more difficult for me, it just becomes less and less attractive. I think it is really on the entrepreneurs and significant investors that Australia could sharpen up in comparison.

In particular, AVCAL argues in relation to the Venture Capital Entrepreneur visa that the investment threshold is prohibitive, since a 'foreign investor would have to be sufficiently successfully and well known to the Australian venture capital investor to be able to secure $\$ 1 \mathrm{~m}$ investment, as the ability of funding at that level is scarce and contested' (AVCAL 2014, p. 3). It argues that Australia would be better off attracting businesses at the early or start-up phase with less than $\$ 1$ million backing. It suggests that the investment amount could be reduced to $\$ 100,000$ to be competitive with other jurisdictions.

Any reduction in the threshold financial amounts across the BIIP will need to be carefully considered. Lowering the threshold too much might have the unintended consequence of attracting lower quality applicants, while not lowering the threshold enough may make the program less attractive compared to other jurisdictions. For the Venture Capital Entrepreneur visa stream, where demand has been non-existent, a lowering of the financial threshold appears sensible. For other visas under the BIIP, an initial reduction in the threshold financial amount is warranted, but further revision may be necessary depending on the impact on demand.

\section{Conclusion}

In a globalized economy marked by fluid movements of human and economic capital, many economies are seeking to leverage the positive links between migration and innovation. Migration can contribute positively to innovation through skills diversification, positive spillovers and the creation of a 'creative class'.

Australia's migration policies - through the Business Innovation and Investment Program - has so far failed in aiding innovation and entrepreneurship. Reform of the BIIP is needed to better align immigration and innovation policy. While the changes to the 'complying investment' criterion to require mandatory investment into venture capital is a step in the right direction, the government could further leverage investments through co-investment schemes. Beyond this, broader reform of the BIIP is required to relax stringent visa criteria in order to attract more persons with business acumen and entrepreneurial talent.

While the innovation needs of every economy will differ, Australia's experience provides some important lessons for other economies. The analysis shows that 
aligning innovation and migration policies requires a delicate balance between offering the right incentives to attract investors and entrepreneurs, while at the same time, ensuring that migration outcomes result in a positive contribution to the innovation system. Such migration programs need constant monitoring and policy adjustments to ensure that they are competitive with the offerings of other countries and remain effective in aiding innovation and entrepreneurship. 


\section{Appendix A}

\begin{tabular}{|c|c|c|}
\hline \multicolumn{3}{|c|}{ Innovation Points Test } \\
\hline Factor & Description & Points \\
\hline \multirow{6}{*}{ Age } & 18-24 years & 20 \\
\hline & 25-32 years & 30 \\
\hline & 33-39 years & 25 \\
\hline & 40-44 years & 20 \\
\hline & 45-54 years & 15 \\
\hline & 55 and older & 0 \\
\hline \multirow{2}{*}{$\begin{array}{l}\text { English language } \\
\text { ability }\end{array}$} & Vocational English & 5 \\
\hline & Proficient English & 10 \\
\hline \multirow[t]{2}{*}{ Qualifications } & $\begin{array}{l}\text { Australian trade certificate, diploma or bachelor degree by an } \\
\text { Australian education institute; or } \\
\text { a bachelor qualification recognised by an education institution of a } \\
\text { recognised standard }\end{array}$ & 5 \\
\hline & $\begin{array}{l}\text { Bachelor degree in business, science or technology by an Australian } \\
\text { institution; or a bachelor qualification by an education institution of a } \\
\text { recognised standard }\end{array}$ & 10 \\
\hline Special endorsement & $\begin{array}{l}\text { The nominating state or territory government agency could decide } \\
\text { that your proposed business is of unique and important benefit to the } \\
\text { state or territory where the nominating government agency is located }\end{array}$ & 10 \\
\hline \multirow{5}{*}{ Financial assets } & $\begin{array}{l}\text { Net business and personal assets of you, your partner or you and } \\
\text { your partner combined in each of the preceding two years of at least: }\end{array}$ & \\
\hline & AUD800 000 & 5 \\
\hline & AUD1.3 million & 15 \\
\hline & AUD1.8 million & 25 \\
\hline & AUD2.25 million & 35 \\
\hline \multirow{5}{*}{ Business turnover } & $\begin{array}{l}\text { Annual turnover in your main business during a period of at least two } \\
\text { years of the preceding four fiscal years of at least: }\end{array}$ & \\
\hline & AUD500 000 & 5 \\
\hline & AUD1 million & 15 \\
\hline & AUD1.5 million & 25 \\
\hline & AUD2 million & 35 \\
\hline
\end{tabular}




\begin{tabular}{|l|l|l|}
\hline \multirow{2}{*}{$\begin{array}{l}\text { Business Innovation } \\
\text { stream only }\end{array}$} & $\begin{array}{l}\text { You have held one or more businesses before you were invited to } \\
\text { apply for the visa for: }\end{array}$ & \\
\cline { 2 - 3 } Business experience & Not less than four years within the preceding five years & 10 \\
\cline { 2 - 3 } & Not less than seven years within the preceding eight years & 15 \\
\hline \multirow{2}{*}{ Investor stream only } & Eligible investment of at least AUD100 000 held for: & 10 \\
\cline { 2 - 3 } Investor experience & At least four years before the time of invitation to apply for the visa & 15 \\
\hline & At least seven years before the time of invitation to apply for the visa & 15 \\
\hline \multirow{3}{*}{$\begin{array}{l}\text { Business innovation } \\
\text { qualifications }\end{array}$} & Evidence of registered patents or registered designs & 10 \\
\hline \multirow{2}{*}{$\begin{array}{l}\text { At the time of } \\
\text { invitation to apply for } \\
\text { the visa: }\end{array}$} & Evidence of registered trademarks & 5 \\
\cline { 2 - 3 } & Evidence of formal joint venture agreements & 15 \\
\hline & Evidence of export trade & 10 \\
\hline & Evidence of receipt of grants or venture capital funding & 10 \\
\hline \multirow{2}{*}{$\begin{array}{l}\text { State or territory } \\
\text { nomination }\end{array}$} & Special endorsement (limited places) & 10 \\
\hline
\end{tabular}

Source: Department of Immigration and Border Protection 2012, Innovation points test for the Business Innovation and Investment Program

\section{References}

Austrade 2015a, SIV \& PIV Complying Investment Framework (CIF) to commence 1 July 2015, viewed 18 May 2015, http://www.austrade.gov.au/ArticleDocuments/1358/SIV-PIV-Complyinginvestment-framework.pdf.aspx

Austrade 2015b. SIV \& PIV Draft Complying Investment Options for Discussion, viewed 10 May 2015, http://www.austrade.gov.au/ArticleDocuments/1350/SIV-PIV-complying-investment-optionsdraft.pdf.aspx

Australian Bureau of Statistics 2014a, 5260.0.55.002 - Estimates of Industry Multifactor Productivity 2013-14, viewed 4 April 2015, http://www.abs.gov.au/ausstats/abs@.nst/mf/5260.0.55.002

Australian Bureau of Statistics 2014b, 8158.0 - Innovation in Australian Business, Barriers to Innovation 2012-13, viewed 4 April 2015, http://www.abs.gov.au/ausstats/abs@.nsf/mf/8158.0

Australian Capital Territory Government 2014, Submission to the Australian Senate Joint Standing Committee on Migration's Inquiry into the Business Innovation and Investment Programme.

Australian Government 2014, Industry Innovation and Competitiveness Agenda: An action plan for a stronger Australia, Canberra.

Australian Private Equity and Venture Capital Association Limited 2015, Submission to Austrade's Proposed Changes to the Investor Visa Programmes.

Australian Private Equity and Venture Capital Association Limited 2014a, 2014 Yearbook: Australian Private Equity and Venture Capital Activity Report.

Australian Private Equity and Venture Capital Association Limited 2014b, Submission to Senate Standing Committee on Economics on Australia's Innovation System. 
Australian Private Equity and Venture Capital Association Limited 2014c, Submission to the Australian Senate Joint Standing Committee on Migration's Inquiry into the Business Innovation and Investment Programme.

Commonwealth of Australia 2014, Australian Senate Joint Standing Committee on Migration's Inquiry into the Business Innovation and Investment Programme, Thursday 21 June 21014: Official Hansard

Australian Senate Joint Standing Committee on Migration (JSCM) 2015, Report of the Inquiry into the Business Innovation and Investment Programme, Canberra.

Bosetti, V., Cattaneo, C., Verdolini, E. 2012, Migration, Cultural Diversity and Innovation: A European Perspective, Nota Di Lavoro 69.2012, viewed 13 March 2015, http://www.econstor.eu/bitstream/10419/72987/1/727404105.pdf

Centre for Enterprise and Economic Development Research, Middlesex University Business School, Sanders Thomas Ltd 2012, Early assessment of the UK Innovation Investment Fund, Department for Business, Innovation \& Skills.

Minister for Immigration and Citizenship 2012, Legislative Instrument IMMI 12/106 - Securities in which an investment is a designated investment for the purposes of subclasses $162,165,188$, $405,888,891 \& 893$.

Cutler, T. 2008, Venturous Australia: Building Strength in Innovation, Department of Innovation, Industry, Science and Research, Canberra.

Department of Immigration and Border Protection (DIBP) 2015a, Fact sheet 27 - Business Migration, viewed 20 March 2015, https://www.immi.gov.au/media/fact-sheets/27business.htm

Department of Immigration and Border Protection (DIBP) 2015b, Significant Investor Visa Statistics, viewed 5 March 2015, http://www.immi.gov.au/pub-res/Pages/statistics/significant-investor-visastatistics.aspx.

Department of Immigration and Border Protection 2014, Submission to the Australian Senate Joint Standing Committee on Migration's Inquiry into the Business Innovation and Investment Programme

Department of Immigration and Citizenship 2012, Frequently Asked Questions - Reforms to the Business Skills Program July 2012, viewed 10 March 2015, http://www.immi.gov.au/skilled/business/_pdf/faq-reforms-business-skills-program.pdf

Department of Immigration and Citizenship 2009, Select Skills: Principles for a New Migration Occupations in Demand List, viewed 10 March 2015, http://www.immi.gov.au/skilled/generalskilled-migration/modl-review/_pdf/issue1.pdf

Department of Industry and Science 2014, Australian Innovation System Report - 2014, Department of Industry and Science.

Department of Innovation, Industry, Science and Research 2009, Submission to the House of Representatives Standing Committee on Economics' Inquiry into the Raising the Level of Productivity Growth in the Australian Economy.

Duleep, H., Jaeger, D., Regets, M. 2012, How Immigration May Affect U.S. Native Entrepreneurship: Theoretical Building Blocks and Preliminary Results, IZA Discussion Paper No. 6677.

Economic Development Board of Singapore 2015, Global Investment Programme, viewed 13 March 2015, http://www.ifaq.gov.sg/EDB/apps/fcd_faqmain.aspx\#FAQ_34995.

Florida, R. 2003, The Rise of the Creative Class and How it's Transforming Work, Leisure, Community and Everyday Life, Basic Books, New York.

Chellaraj, G., Maskus, K., Mattoo, A. 2005, The Contribution of Skilled Immigration and International Graduate Students to U.S. Innovation, Working Paper Series 3588, World Bank, Washington, DC.

Government of Canada 2015, Immigrant Investor Venture Capital Pilot Program, viewed 10 March 2015, http://www.cic.gc.ca/english/immigrate/business/iivc/index.asp. 
Hughes, A, Foster, J, Metcalfe, S, 2012, Systems Thinking, Market Failure, and the Development of Innovation Policy: the case of Australia, Research Policy 40, pp. 1145-1156.

Hunt, J., Gauthier-Loiselle, M. 2009, How Much does Immigration Boost Innovation? IZA Discussion Paper No. 3921.

Immigration Solution Lawyers 2014, Submission to the Australian Senate Joint Standing Committee on Migration's Inquiry into the Business Innovation and Investment Programme.

Islam, A., Islam, F., Nguyen, C. 2013, Skilled Migration, Innovation and Ages of Native-born American, Discussion Paper 10/13, Monash University Department of Economics.

Jensen, P. 2014, Understanding the Impact of Migration on Innovation, Australian Economic Review 47, pp. 240-50.

Knight, F. 1921, Risk, Uncertainty and Profit, Houghton Mifflin Company, Boston, MA.

Levingston, C. 2014, Submission to the Australian Senate Joint Standing Committee on Migration's Inquiry into the Business Innovation and Investment Programme.

Migration Institute of Australia 2014, Submission to the Australian Senate Joint Standing Committee on Migration's Inquiry into the Business Innovation and Investment Programme.

Migration Regulations 1994 (Cth).

Minister for Immigration, Multicultural Affairs and Citizenship, T.B., 2013. Legislative Instrument IMMI 13/092 - Eligible Managed Funds Investment.

National Research Foundation: Prime Minister's Office Singapore 2014, Early Stage Venture Fund, iewed 15 March 2015, http://www.nrf.gov.sg/innovation-enterprise/national-framework-forresearch-innovation-and-enterprise/early-stage-venture-fund.

Niebuhr, A 2010. Migration and innovation: Does Cultural Diversity Matter for Regional R\&D Activity? Papers in Regional Science 89, pp. 563-585.

Northern Territory Government 2014, Submission to the Australian Senate Joint Standing Committee on Migration's Inquiry into the Business Innovation and Investment Programme.

NSW Trade and Investment, 2014. Submission to the Australian Senate Joint Standing Committee on Migration's Inquiry into the Business Innovation and Investment Programme.

OECD 2014, Entrepreneurship at a Glance 2014, OECD Publishing.

OECD 2005, Oslo Manual: Guidelines for Collecting and Interpreting Innovation Data, 3rd ed, OECD and Eurostat.

Robb, A. 2014, Media Release: Premium Investor Visa to Promote Innovation, viewed 10 March 2015, http://trademinister.gov.au/releases/Pages/2014/ar_mr_141017.aspx

Rockwell Oliver 2014, Submission to the Australian Senate Joint Standing Committee on Migration's Inquiry into the Business Innovation and Investment Programme.

Schumpeter, J. 1934, The Theory of Economic Development: An Inquiry into Profits, Capital, Credit, Interest, and the Business Cycle, Harvard University Press, Cambridge, MA.

South Australian Government 2014, Submission to the Australian Senate Joint Standing Committee on Migration's Inquiry into the Business Innovation and Investment Programme.

SPRING Startup Enterprise Development Scheme 2010, Spring Seeds - Frequently Asked Questions, viewed 13 March 2015, http://www.spring.gov.sg/NurturingStartups/SEEDS/Documents/SEEDS_FAQs.pdf

Stephan, P., Levin, S. 2001, Exceptional Contributions to U.S. Science by the Foreignborn and Foreigneducated, Population Research and Policy Review 20, pp. 59-79. 
Stuen, E., Mobarak, A., Maskus, K. 2012, Skilled Immigration and Innovation: Evidence from Enrolment Fluctuations in U.S. Doctoral Programmes, The Economic Journal Volume122, Issue 565, pp. 143-176.

The Treasury, Department of Industry, Innovation, Science, Research and Tertiary Education 2012, Review of Venture Capital and Entrepreneurial Skills (Final Report).

Van Zyl, D. 2014, Submission to the Australian Senate Joint Standing Committee on Migration's Inquiry into the Business Innovation and Investment Programme.

Zucker, L., Darby, M. 2007, Star Scientists, Innovation and Regional National Immigration, NBER Working Paper 13547, National Bureau of Economic Research, Cambridge, MA. 